\title{
Nucleophilic Substitution Reactions of $\alpha$-Chloroacetanilides with Pyridines in Dimethyl Sulfoxide
}

\author{
Shuchismita Dey, Keshab Kumar Adhikary, Chan Kyung Kim, Bon-Su Lee, and Hai Whang Lee* \\ Department of Chemistry, Inha University, Incheon 402-751,Korea.*E-mail: bslee@inha.ac.kr; hwlee@inha.ac.kr \\ Received February 11, 2005
}

\begin{abstract}
The kinetic studies of the reactions of $\alpha$-chloroacetanilides $\left(\mathrm{YC}_{6} \mathrm{H}_{4} \mathrm{NRC}(=\mathrm{O}) \mathrm{CH}_{2} \mathrm{Cl} ; \mathrm{R}=\mathrm{H}(4)\right.$ and $\left.\mathrm{CH}_{3}(\mathbf{5})\right)$ with pyridines have been carried out in dimethyl sulfoxide at $95{ }^{\circ} \mathrm{C}$. The pyridinolysis rates are faster with 4 than with 5 whereas the aminolysis rates with benzylamines are faster with 5 than with $\mathbf{4}$. The Brønsted $\beta_{\mathrm{X}}$ values are in the range from 0.30 to 0.32 and the cross-interaction constants, $\rho_{\mathrm{XY}}$, are small negative values; $\rho_{\mathrm{XY}}=-0.06$ and -0.10 for 4 and $\mathbf{5}$, respectively. Based on these and other results, the pyridinolyses of $\alpha-$ chloroacetanilides are proposed to proceed via a stepwise mechanism with rate-limiting addition of the nucleophile to the carbonyl group to form zwitterionic tetrahedral intermediate $\left(\mathrm{T}^{ \pm}\right)$followed by a bridged type transition state to expel the leaving group.
\end{abstract}

Key Words : Pyridinolyses of $\alpha$-chloroacetanilides, Cross-interaction constants, Stepwise mechanism

\section{Introduction}

The nucleophilic substitution reactions of $\alpha$-halocarbonyl compounds have attracted considerable attention of theoretical $^{1}$ as well as experimental organic chemists, ${ }^{2}$ mainly because of the rate-enhancing effect of the $\alpha$-carbonyl group. $^{2 a, b, c, 3}$ Although a variety of mechanism has been proposed for $\alpha$-carbonyl system, by different group of authors, especially in case of phenacyl derivatives, three types among them are conidered to be worthy of note: (i) stepwise mechanism with a prior addition of the nucleophile (XN) to the carbonyl group, ${ }^{4} \mathbf{1}$, (ii) bridging of the nucleophile between the $\alpha$-carbon and the carbonyl carbon in the transition state (TS), ${ }^{3,4 c, 1 a, b} \mathbf{2}$, (iii) concerted displacement with an enolate-like $\mathrm{TS}^{5} \mathbf{3}$.<smiles>[Y]CC([14CH3])([N])[O-]</smiles>

1

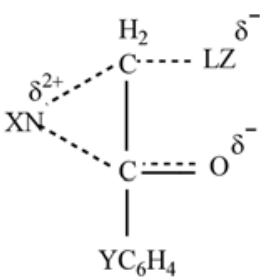

2

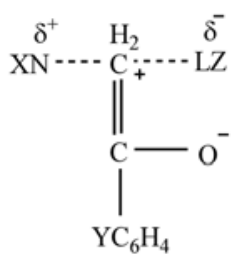

3
In a series of works, we reported an unified mechanism in which the reaction proceeds through an addition intermediate (1) with bridged type TS $(2)^{6}$ in the expulsion of the leaving group, $\mathrm{LZ}^{-}$. In a previous work, ${ }^{6 \mathrm{~d}}$ the aminolyses of $\alpha$-chloroacetanilides $\left(\mathrm{YC}_{6} \mathrm{H}_{4} \mathrm{NRC}(=\mathrm{O}) \mathrm{CH}_{2} \mathrm{Cl} ; \mathrm{R}=\mathrm{H}\right.$ and $\mathrm{CH}_{3}$ ) with benzylamines in dimethyl sulfoxide are found to proceed through a stepwise mechanism with rate-limiting expulsion of the chloride leaving group from a zwitterionic tetrahedral intermediate, $\mathrm{T}^{ \pm}$, with a bridged type transition state (2) for which the cross-interaction constants, ${ }^{7} \rho_{\mathrm{XY}}$ in eqs. 1, where $\mathrm{X}$ and $\mathrm{Y}$ denote substituents in the nucleophile and substrate, are positive; $\rho_{\mathrm{XY}}=+0.21$ and +0.18 with $\mathrm{R}=\mathrm{H}$ (4) and $\mathrm{CH}_{3}(5)$, respectively.

$$
\begin{gathered}
\log \left(k_{\mathrm{XY}} / k_{\mathrm{HH}}\right)=\rho_{\mathrm{X}} \sigma_{\mathrm{X}}+\rho_{\mathrm{Y}} \sigma_{\mathrm{Y}}+\rho_{\mathrm{XY}} \sigma_{\mathrm{XY}} \\
\rho_{\mathrm{XY}}=\partial \rho_{\mathrm{X}} / \partial \sigma_{\mathrm{Y}}=\partial \rho_{\mathrm{Y}} / \partial \sigma_{\mathrm{X}}
\end{gathered}
$$

In the pyridinolysis of phenacyl bromides $\left(\mathrm{YC}_{6} \mathrm{H}_{4} \mathrm{C}(=\mathrm{O})\right.$ $\mathrm{CH}_{2} \mathrm{Br}$ ) in $\mathrm{MeCN}$, a change of $\rho_{\mathrm{XY}}$ from a large positive $\left(\rho_{\mathrm{XY}}=+1.36\right)$ to a small positive $\left(\rho_{\mathrm{XY}}=0.09\right)$ value indicates a rate-determining step change at the breakpoint $\left(\mathrm{p} K_{\mathrm{a}}^{\mathrm{o}}=3.2-3.6\right)$ from breakdown to formation of a zwitterionic intermediate, $\mathrm{T}^{ \pm}\left(\mathbf{1}\right.$ with $\mathrm{XN}^{+}=$pyridinium ion $)$as the pyridine basicity is increased. ${ }^{6 \mathrm{c}}$ To gain further evidence in support of our unified mechanism $(\mathbf{1}+\mathbf{2})$ for the $\alpha$-halocarbonyl systems, we carried out kinetic studies of the pyridinolysis of $\alpha$-chloroacetanilides ( 4 and 5 with $\mathrm{R}=\mathrm{H}$ and $\mathrm{CH}_{3}$, respectively in eq. 2) in dimethyl sulfoxide at $95{ }^{\circ} \mathrm{C}$.

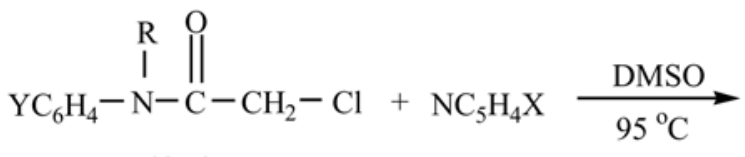

$(4,5)$

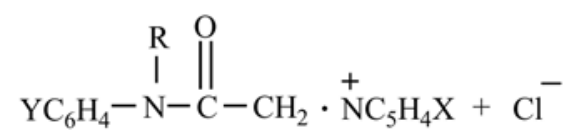

$\mathrm{R}=\mathrm{H}$ (4) and $\mathrm{CH}_{3}$ (5).

$\mathrm{Y}=p-\mathrm{CH}_{3} \mathrm{O}, p-\mathrm{CH}_{3}, \mathrm{H}, p-\mathrm{Cl}$ and $p-\mathrm{NO}_{2}$.

$\mathrm{X}=p-\mathrm{CH}_{3} \mathrm{O}, p-\mathrm{CH}_{3}, m-\mathrm{CH}_{3}$ (only for $\mathbf{5}$ ), $\mathrm{H}$,

$m-\mathrm{C}_{6} \mathrm{H}_{5}$ and $m-\mathrm{COCH}_{3}$.

\section{Results and Discussion}

The reactions followed the clean second-order rate law given by eqs. 3 and 4, where [Py] is the pyridine concentration. The pseudo-first-order rate constants observed $\left(k_{\text {obsd }}\right)$

$$
\begin{gathered}
\mathrm{d}\left[\mathrm{Cl}^{-}\right] / \mathrm{dt}=k_{\text {obsd }}[\text { substrate }] \\
k_{\text {obsd }}=k_{0}+k_{\mathrm{N}}[\mathrm{Py}]
\end{gathered}
$$


obeyed eq. 4 , for all reactions with negligible $k_{0}(\cong 0)$ in DMSO. The second-order rate constants for pyridinolysis, $k_{\mathrm{N}}\left(\mathrm{M}^{-1} \mathrm{~s}^{-1}\right)$, summarized in Table 1 and Table 2 for $\mathbf{4}$ and $\mathbf{5}$, respectively, were obtained as the slopes of the plots of $k_{\text {obsd }}$ against pyridine concentrations, [Py], in eq. (4). No thirdorder or higher order terms were detected, and no complications were found in the determination of $k_{\text {obsd }}$ or in the linear plots of eq. 4. The rate is faster with a stronger nucleophile and with a stronger electron withdrawing group in the substrate, $\mathbf{4}$ and $\mathbf{5}$ as normally observed for a typical nucleophilic substitution reaction. The rate constants for the pyridinolysis of $\alpha$-chloroacetanilides are found to be smaller than those for the aminolysis with benzylamines e.g. for $\mathrm{Y}=\mathrm{H},(4) ; k_{\mathrm{N}}=7.63 \times 10^{-3} \mathrm{M}^{-1} \mathrm{~s}^{-1}$ for benzylamine $\left(\mathrm{p} K_{\mathrm{a}}=\right.$ 9.38 in water) in DMSO at $55{ }^{\circ} \mathrm{C}^{6 \mathrm{~d}}$ and $k_{\mathrm{N}}=1.02 \times 10^{-3}$ $\mathrm{M}^{-1} \mathrm{~s}^{-1}$ for pyridine ( $\mathrm{p} K_{\mathrm{a}}=5.21$ in water) in DMSO at $95{ }^{\circ} \mathrm{C}$ as the basicity (nucleophilicity) of pyridine is smaller than that of benzylamine. The Brønsted coefficients $\beta_{\mathrm{X}}\left(\beta_{\text {nuc }}\right)$, Hammett constants $\rho_{\mathrm{X}}\left(\rho_{\text {nuc }}\right)$ and $\rho_{\mathrm{Y}}$ values and the crossinteraction constants $\rho_{\mathrm{XY}}$ values are also shown in Table 1 and 2 for $\mathbf{4}$ and $\mathbf{5}$, respectively. The $\mathrm{p} K_{\mathrm{a}}$ values of pyridines used in the Brønsted plots were those determined in water as shown in Figures 1 (4) and $2(\mathbf{5})$, respectively.

The Brønsted coefficients in Tables 1 and 2 could be in error since the rate data in Tables (in DMSO) should be plotted using $\mathrm{p} K_{\mathrm{a}}$ values measured in DMSO. However the $\beta_{\mathrm{X}}$ values, determined by the $\mathrm{p} K_{\mathrm{a}}$ values in water, are

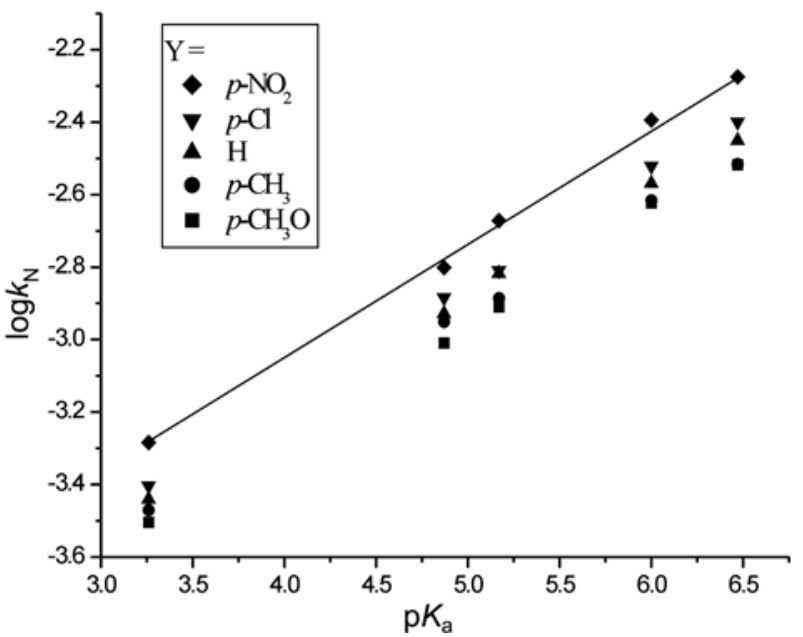

Figure 1. Brønsted plots of $\log k_{\mathrm{N}} v s . \mathrm{p} K_{\mathrm{a}}(\mathrm{X})$ for the pyridinolysis of Y- $\alpha$-chloroacetanilides (4) in DMSO at $95{ }^{\circ} \mathrm{C}$.

considered to provide reasonable guides, as has been shown for the $\beta_{\mathrm{X}}$ values in the pyridinolysis of $N$-methyl- $N$-aryl carbamoyl chloride $\left(\mathrm{YC}_{6} \mathrm{H}_{4} \mathrm{~N}\left(\mathrm{CH}_{3}\right) \mathrm{C}(=\mathrm{O}) \mathrm{Cl}\right)$ in DMSO. ${ }^{10 \mathrm{a}}$ The plots of $\mathrm{p} K_{\mathrm{a}}(\varepsilon)$ (in five solvents including water) vs. $\sigma$ gave the slopes, $\rho_{\mathrm{s}}(\varepsilon)$, which is linear with Onsager dielectric function $(\varepsilon-1) /(2 \varepsilon+1)$ with $\mathrm{r}=0.999$. Spillane $e t$ al. ${ }^{11}$ reported that the Brønsted coefficients $\left(\beta_{\mathrm{X}}\right)$ for the reaction of $\mathrm{N}$-phenylsulfamoyl chloride $\left(\mathrm{YC}_{6} \mathrm{H}_{4} \mathrm{NHSO}_{2} \mathrm{Cl}\right)$ with anilines in DMSO are similar when determined using

Table 1. Second-order rate constants, $\left(k_{\mathrm{N}} \times 10^{4} / \mathrm{M}^{-1} \mathrm{~s}^{-1}\right)$ and selectivity parameters ${ }^{a}$ for the pyridinolysis of Y- $\alpha$-chloroacetanilides in DMSO at $95{ }^{\circ} \mathrm{C}$

\begin{tabular}{ccccccc}
\hline $\mathrm{Y}$ & $p-\mathrm{OCH}_{3}$ & $p-\mathrm{CH}_{3}$ & $\mathrm{H}$ & $p-\mathrm{Cl}$ & $p-\mathrm{NO}_{2}$ & $\rho_{\mathrm{Y}}{ }^{b}$ \\
\hline$p-\mathrm{CH}_{3} \mathrm{O}$ & 30.3 & 30.5 & 35.4 & 39.9 & 53.1 & $0.24 \pm 0.01$ \\
$p-\mathrm{CH}_{3}$ & 23.8 & 24.2 & 27.0 & 30.1 & 40.4 & $0.22 \pm 0.01$ \\
$\mathrm{H}$ & 12.3 & 13.0 & 15.2 & 15.5 & 21.3 & $0.22 \pm 0.01$ \\
$m-\mathrm{C}_{6} \mathrm{H}_{5}$ & 9.80 & 11.2 & 11.8 & 13.1 & 15.8 & $0.18 \pm 0.01$ \\
$m-\mathrm{COCH}_{3}$ & 3.13 & 3.39 & 3.62 & 3.95 & 5.20 & $0.20 \pm 0.01$ \\
$\rho_{\mathrm{X}}{ }^{c}$ & $-1.55 \pm 0.04$ & $-1.49 \pm 0.05$ & $-1.54 \pm 0.04$ & $-1.56 \pm 0.03$ & $-1.58 \pm 0.05$ & \\
$\beta_{\mathbf{X}}{ }^{d}$ & $0.31 \pm 0.01$ & $0.30 \pm 0.01$ & $0.31 \pm 0.01$ & $0.32 \pm 0.01$ & $0.32 \pm 0.01$ & $\rho_{\mathrm{XY}}{ }^{e}=-0.06 \pm 0.05$ \\
\hline
\end{tabular}

${ }^{a} \sigma$ values were taken from ref. 8. The $\beta_{\mathrm{x}}$ values were determined using $\mathrm{p} K_{\mathrm{a}}$ values in water. The $\mathrm{p} K_{\mathrm{a}}$ values were taken from ref. 9. ${ }^{b}$ Correlation coefficients, $\mathrm{r}$, were better than 0.990 in all cases. ${ }^{c} \mathrm{r} \geq 0.998 .{ }^{d} \mathrm{r} \geq 0.999 .{ }^{e} \mathrm{r}=0.997$

Table 2. Second-order rate constants, $\left(k_{\mathrm{N}} \times 10^{4} / \mathrm{M}^{-1} \mathrm{~s}^{-1}\right)$ and selectivity parameters ${ }^{a}$ for the pyridinolysis of $N$-methyl-Y- $\alpha$-chloroacetanilides in DMSO at $95{ }^{\circ} \mathrm{C}$

\begin{tabular}{ccccccc}
\hline $\mathrm{X}$ & $p-\mathrm{OCH}_{3}$ & $p-\mathrm{CH}_{3}$ & $\mathrm{H}$ & $p-\mathrm{Cl}$ & $p-\mathrm{NO}_{2}$ & $\rho_{\mathrm{Y}}^{b}$ \\
\hline$p-\mathrm{CH}_{3} \mathrm{O}$ & 21.0 & 22.8 & 26.7 & 35.0 & 52.6 & $0.40 \pm 0.04$ \\
$p-\mathrm{CH}_{3}$ & 15.7 & 16.7 & 18.6 & 23.2 & 33.0 & $0.32 \pm 0.03$ \\
$m-\mathrm{CH}_{3}$ & 11.1 & 11.3 & 13.4 & 17.0 & 26.1 & $0.40 \pm 0.05$ \\
$\mathrm{H}$ & 9.46 & 9.51 & 10.2 & 12.8 & 17.1 & $0.23 \pm 0.03$ \\
$m-\mathrm{C}_{6} \mathrm{H}_{5}$ & 7.51 & 7.72 & 8.46 & 10.8 & 15.1 & $0.30 \pm 0.02$ \\
$m-\mathrm{COCH}_{3}$ & 2.29 & 2.33 & 2.58 & 3.21 & 4.67 & $0.31 \pm 0.02$ \\
$\rho_{\mathrm{X}}{ }^{c}$ & $-1.48 \pm 0.05$ & $-1.52 \pm 0.04$ & $-1.56 \pm 0.02$ & $-1.58 \pm 0.02$ & $-1.60 \pm 0.05$ & \\
$\beta_{\mathbf{X}}{ }^{d}$ & $0.30 \pm 0.01$ & $0.30 \pm 0.01$ & $0.31 \pm 0.01$ & $0.32 \pm 0.01$ & $0.32 \pm 0.01$ & $\rho_{\mathrm{XY}}{ }^{e}=-0.10 \pm 0.05$ \\
\hline
\end{tabular}




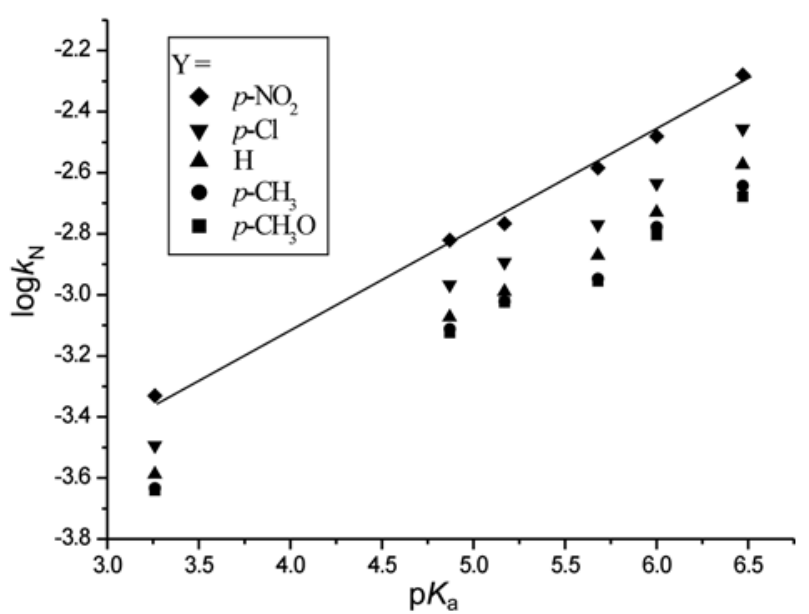

Figure 2. Brønsted plots of $\log k_{\mathrm{N}} v s$. $\mathrm{p} K_{\mathrm{a}}(\mathrm{X})$ for the pyridinolysis of $N$-methyl-Y- $\alpha$-chloroacetanilides (5) in DMSO at $95^{\circ} \mathrm{C}$.

$\mathrm{p} K_{\mathrm{a}}$ values of anilines measured in water $\left(\beta_{\mathrm{X}}=0.69\right)$ and in DMSO $\left(\beta_{\mathrm{X}}=0.62\right)$. This provides evidence in support of correlating the rate data determined in DMSO with the $\mathrm{p} K_{\mathrm{a}}$ values measured in water.

We propose for the present series of reactions, the stepwise mechanism with rate limiting formation of $\mathrm{T}^{ \pm}$, followed by bridged type transition state to expel the chloride leaving group, in eq. 5 where $k_{\mathrm{N}}=k_{\mathrm{a}}$ since $k_{-\mathrm{a}}<<k_{\mathrm{b}}$. Nucleophile of pyridine attacks

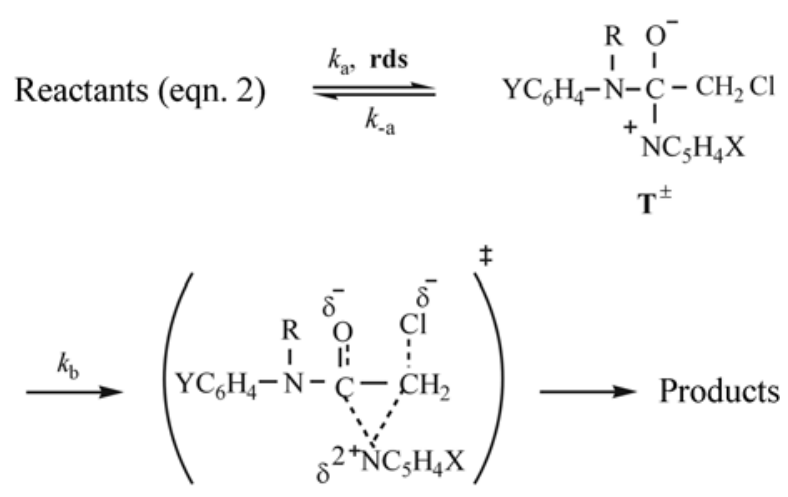

TS

firstly on carbonyl carbon (not $\alpha$-carbon) to form the zwitterionic intermediate, $\mathrm{T}^{ \pm}$, in eq. 5 in the rate-determining step. In a previous work, ${ }^{6 \mathrm{~d}}$ we have explained that nucleophile initially interacts more strongly with carbonyl carbon ( $\left.\pi^{*} \mathrm{C}=\mathrm{O}\right)$ than with $\alpha$-carbon $\left(\sigma^{*} \mathrm{C}-\mathrm{Cl}\right)$ on $\mathrm{MO}$ theoretical approach. $^{12}$ In the second step, the departing pyridine molecule shifts to the $\alpha$-carbon with simultaneous expulsion of $\mathrm{Cl}^{-}$leaving group, in a bridging type (2) transition state structure. This is reasonable, since in the intermediate there is only one LUMO $\left(\sigma^{*} \mathrm{C}-\mathrm{Cl}\right)$ left for the amine to attack. The proposed mechanism for the present work can be justified on the following grounds.

(1) In the present system, we observed faster rates with $\mathbf{4}$ than with $\mathbf{5}$, compairing $k_{\mathrm{N}}$ values in Table 1 and 2 . This is reasonable, because $\mathrm{CH}_{3}$ group is a stronger electron donor (compare to $\mathrm{H}$ ), which donate electron to the anilino nitrogen. As a result, electron density on carbonyl carbon increases in $5\left(\mathrm{R}=\mathrm{CH}_{3}\right)$ rather than in $4(\mathrm{R}=\mathrm{H})$ and nucleophile attacks less strongly in the former, i.e., the initial ratelimiting carbonyl addition step $\left(k_{\mathrm{a}}\right)$ is retarded. In contrast, the reaction rates of $\alpha$-chloroacetanilides with benzylamines in DMSO are faster with $5\left(\mathrm{R}=\mathrm{CH}_{3}\right)$ than with $4(\mathrm{R}=\mathrm{H})$ which was taken to imply the rate-limiting expulsion of the leaving group from $\mathrm{T}^{ \pm}$. This is in accord with the sequence of amine expulsion rate from $\mathrm{T}^{ \pm}$; benzylamines $>$secondary alicyclic amines $>$ anilines $>$ pyridines. ${ }^{13}$ The aminolysis of $\alpha$-chloroacetanilides is one of the typical models to show the sequence of the amine expulsion rate from $T^{ \pm}$explicitly. In case of the aminolysis of $\alpha$-chloroacetanilides with benzylamines, the benzylamine expulsion rate $\left(k_{-\mathrm{a}}\right)$ from $\mathrm{T}^{ \pm}$is faster than the leaving group expulsion rate $\left(k_{\mathrm{b}}\right), k_{-\mathrm{a}}>>k_{\mathrm{b}}$, and the leaving group expulsion is rate-determining step. On the other hand, the pyridine expulsion rate from $\mathrm{T}^{ \pm}$is slower than the leaving group expulsion rate, $k_{\mathrm{b}}>>k_{-\mathrm{a}}$, and the bond formation step is rate-determining one for the pyridinolysis of $\alpha$-chloroacetanilides. For the aminolysis of $\alpha$-chloroacetanilides with benzylamines, the leaving group expulsion from $\mathrm{T}^{ \pm}$is enhanced by a stronger electron donating $\mathrm{R}\left(\mathrm{CH}_{3}\right.$ relative to $\mathrm{H})$ which leads to faster rates with $5\left(\mathrm{R}=\mathrm{CH}_{3}\right)$ than with $4(\mathrm{R}=\mathrm{H})$.

(2) The sign of cross-interaction constants $\rho_{\mathrm{XY}}$ are negative but very small magnitude, $\rho_{\mathrm{XY}}=-0.06$ and -0.10 for the reactions of $\mathbf{4}$ and $\mathbf{5}$, respectively in contrast to the positive $\rho_{\mathrm{XY}}=+0.21$ and +0.18 for the reactions of $\mathbf{4}$ and $\mathbf{5}$ with benzylamines, ${ }^{6 \mathrm{~d}}$ respectively. The very small magnitude of $\rho_{\mathrm{XY}}$ in this work is partly ascribed to the intervening NR group in the substrate between the reaction center carbon and the benzene ring i.e., the fall-off by a factor of 2.4-2.8 due to an intervening group. ${ }^{7}$ In all the aminolysis of phenacyl derivatives involving different nucleophiles (benzylamines, anilines or pyridines), different leaving groups (chlorides, bromides or arensulfonates) and different solvents $\left(\mathrm{MeOH}, \mathrm{MeCN}\right.$ or DMSO), the $\rho_{\mathrm{XY}}$ values were positive which were taken to indicate the reactions proceed by a stepwise mechanism with rate-limiting expulsion of the leaving group: $\rho_{\mathrm{XY}}=0.05^{6 \mathrm{e}}$ and $\rho_{\mathrm{XY}}=1.36^{6 \mathrm{c}}$ for the reactions of phenacyl bromides with benzylamines and with pyridines in MeCN, respectively; $\rho_{\mathrm{XY}}=0.02-0.04^{6 \mathrm{~b}}$ and $\rho_{\mathrm{XY}}=0.05-$ $0.14^{6 \mathrm{a}}$ for the reactions of phenacyl benzenesulfonates $\left(\mathrm{YC}_{6} \mathrm{H}_{4} \mathrm{C}(=\mathrm{O}) \mathrm{CH}_{2} \mathrm{OSO}_{2} \mathrm{C}_{6} \mathrm{H}_{4} \mathrm{Z}\right)$ with benzylamines in $\mathrm{MeOH}$ and with anilines in $\mathrm{MeOH}-\mathrm{MeCN}$, respectively; $\rho_{\mathrm{XY}}=0.21$ and $0.18^{6 \mathrm{~d}}$ for the reactions of $\mathbf{4}$ and 5 with benzylamines in DMSO, respectively. The acyl transfer reactions with ratelimiting expulsion of the leaving group also give relatively large positive $\rho_{\mathrm{XY}}$ values: $\rho_{\mathrm{XY}}=0.38-0.42^{14 \mathrm{a}}$ for the reactions of $p$-nitrophenyl benzoates $\left(\mathrm{YC}_{6} \mathrm{H}_{4} \mathrm{C}(=\mathrm{O}) \mathrm{OC}_{6} \mathrm{H}_{4}-p\right.$ $\mathrm{NO}_{2}$ ) with benzylamines in $\mathrm{MeOH} ; \rho_{\mathrm{XY}}=0.53-0.64^{14 \mathrm{~b}}$ for the reactions of benzoic anhydrides $\left(\mathrm{YC}_{6} \mathrm{H}_{4} \mathrm{C}(=\mathrm{O}) \mathrm{OC}(=\mathrm{O})-\right.$ $\left.\mathrm{C}_{6} \mathrm{H}_{5}\right)$ with anilines in $\mathrm{MeOH} ; \rho_{\mathrm{XY}}=1.35-1.49^{15 \mathrm{a}}$ and $0.51-$ $0.61^{15 \mathrm{~b}}$ for the reactions of $S$-phenyl benzoates $\left(\mathrm{YC}_{6} \mathrm{H}_{4} \mathrm{C}\right.$ $\left.(=\mathrm{O}) \mathrm{SC}_{6} \mathrm{H}_{4} \mathrm{Z}\right)$ with anilines in $\mathrm{MeOH}$ and with benzylamines in $\mathrm{MeCN}$, respectively; $\rho_{\mathrm{XY}}=0.61-0.71^{15 \mathrm{c}}$ for the 
reactions of aryl dithiobenzoates $\left(\mathrm{YC}_{6} \mathrm{H}_{4} \mathrm{C}(=\mathrm{S}) \mathrm{SC}_{6} \mathrm{H}_{4} \mathrm{Z}\right)$ with anilines in $\mathrm{MeCN}$. In contrast, all of the $\mathrm{S}_{N} 2$ displacement reactions of various substrates with amines are reported to give negative $\rho_{\mathrm{XY}}$ values. ${ }^{7}$ A stronger electronacceptor substituent in the substrate $\left(\partial \sigma_{\mathrm{Y}}>0\right)$ leads to a greater degree of bond formation $\left(\partial \rho_{\mathrm{X}}<0\right)$ so that $\rho_{\mathrm{XY}}=$ $\partial \rho_{\mathrm{X}} / \partial \sigma_{\mathrm{Y}}$ is negative. For a stepwise reaction with the ratelimiting formation of tetrahedral intermediate, $\mathrm{T}^{ \pm}$, the sign of $\rho_{\mathrm{XY}}$ will be same for the forward reaction of concerted $\mathrm{S}_{N} 2$ processes, ${ }^{7 c, 15 c, 16}$ i.e., $\rho_{\mathrm{XY}}<0$, as shown in the present work. However, as discussed previously ${ }^{6 c}$ in the partitioning of tetrahedral intermediate the rate of expulsion of amines is increased $\left(\partial \rho_{\mathrm{X}}>0\right)$ by a stronger electron-acceptor substituent in the acyl group $\left(\partial \sigma_{\mathrm{Y}}>0\right)^{17}$ so that $\rho_{\mathrm{XY}}=\partial \rho_{\mathrm{X}} /$ $\partial \sigma_{\mathrm{Y}}$ should be positive. Thus the sign and magnitude of $\rho_{\mathrm{XY}}$ would be compensated by the two factors, i.e., $\rho_{\mathrm{XY}}<0$ for bond formation step and $\rho_{\mathrm{XY}}>0$ for amine expulsion from $\mathrm{T}^{ \pm}$. As a result of compensation effects of opposite signs, the $\rho_{\mathrm{XY}}$ values for the reactions of the rate-limiting formation of $\mathrm{T}^{ \pm}$are very small negative or positive: $\rho_{\mathrm{XY}}=-0.06$ and -0.10 for the pyridinolysis of $\mathbf{4}$ and $\mathbf{5}$ (this work) in DMSO, respectively; $\rho_{\mathrm{XY}}=+0.09$ for the rate-limiting formation part of pyridinolysis of phenacyl bromide in $\mathrm{MeCN}^{6 c} ; \rho_{\mathrm{XY}}=$ +0.05 for the aminolysis of aryl dithiobenzoates with benzylamines in MeCN. ${ }^{18}$

(3) The initial rate-limiting formation of $\mathrm{T}^{ \pm}$is also supported by the smaller magnitude of $\beta_{\mathrm{X}}(0.30-0.32$ for both 4 and 5), indicating the degree of bond formation, than those of the aminolysis with benzylamines $\left(\beta_{\mathrm{X}}=0.56-\right.$ $0.87){ }^{6 \mathrm{~d}}$ In case of acyl transfer reactions of aryl dithiobenzoates with benzylamines in $\mathrm{MeCN}$ for which the ratelimiting attack on the thiocarbonyl, $\beta_{\mathrm{X}}=0.19-0.26^{18}$ are found. A biphasic dependence of $\log k_{\mathrm{N}}$ on the pyridine basicity was obtained for aryl dithiobenzoates, ${ }^{19}$ aryl dithioacetates $^{20}$ and aryl furan-2-carbodithioates (c$\left.\mathrm{C}_{4} \mathrm{H}_{3} \mathrm{OC}(=\mathrm{S}) \mathrm{SC}_{6} \mathrm{H}_{4} \mathrm{Z}\right)^{21}$ in $\mathrm{MeCN}$ with a breakpoint at $\mathrm{p} K_{\mathrm{a}}^{\mathrm{o}}$ where the rate-limiting step is changed from bond breaking to bond formation as the basicity of pyridine is increased. The $\beta_{\mathrm{x}}$ values are also small for the rate-limiting formation parts of the acyl transfer reactions of pyridinolysis of aryl dithiobenzoates $\left(\beta_{\mathrm{X}}=0.16-0.18\right),{ }^{19}$ aryl dithioacetates $\left(\beta_{\mathrm{X}}=\right.$ $0.37-0.39)^{20}$ and aryl furan-2-carbodithioates $\left(\beta_{\mathrm{X}}=0.16\right.$ $0.17)^{21}$ in $\mathrm{MeCN}$. In contrast, the $\beta_{\mathrm{X}}$ values are within narrow range of $0.7 \pm 0.1$ for the aminolysis of phenacyl derivatives which proceed stepwise through a zwitterionic tetrahedral intermediate with rate-limiting expulsion of the leaving group; $\beta_{\mathrm{X}}=0.69-0.73^{6 \mathrm{e}}$ and $\beta_{\mathrm{X}}=0.65-0.80^{6 \mathrm{c}}$ for the reactions of phenacyl bromides with benzylamines and with anilines in MeCN, respectively; $\beta_{\mathrm{X}}=0.63-0.76^{6 \mathrm{~b}}$ and $\beta_{\mathrm{X}}=$ $0.65-0.76^{6 \mathrm{a}}$ for the reactions of phenacyl benzenesulfonates with benzylamines in $\mathrm{MeOH}$ and with anilines in $\mathrm{MeOH}-$ $\mathrm{MeCN}$, respectively; $\beta_{\mathrm{X}}=0.56-0.87^{6 \mathrm{~d}}$ and $\beta_{\mathrm{X}}=0.61-0.87^{6 \mathrm{~d}}$ for the reactions of $\mathbf{4}$ and $\mathbf{5}$ with benzylamines in DMSO, respectively. The rate-limiting expulsion parts of pyridinolysis of aryl dithiobenzoates, aryl dithioacetates and aryl furan-2-carbodithioates give $\beta_{\mathrm{X}}=0.71-0.78,{ }^{19} 0.83-0.94^{20}$ and $0.73-0.81,{ }^{21}$ respectively. The large magnitudes of
Brønsted coefficients, $\beta_{\mathrm{X}}\left(\beta_{\text {nuc }}\right) \geq 0.8^{15 b, c, 17 a, 22}$ are normally considered to represent a stepwise mechanism with ratelimiting expulsion of the leaving group. Castro et al. investigated the quinuclidinolysis of ethyl $S$-4-nitrophenyl thiocarbonate $\left(\beta_{\mathrm{X}}=0.85\right)^{13 \mathrm{c}}$ and methyl 4-nitrophenyl carbonate $\left(\beta_{\mathrm{X}}=0.86\right),{ }^{23}$ a stepwise mechanism with ratelimiting breakdown of $\mathrm{T}^{ \pm}$is proposed.

(4) The reactivity-selectivity principle (RSP) does not hold to the studied system, i.e., the faster rate $\left(\alpha_{\mathrm{N}}>0\right)$ is invariably accompanied by a larger magnitude of selectivity parameters, $\partial\left|\rho_{\mathrm{X}}\right|>0, \partial \rho_{\mathrm{Y}}>0$ and $\partial \beta_{\mathrm{X}}>0$ as shown in Tables 1 and 2. The fail of RSP is another criterion for the stepwise mechanism with rate-limiting addition of the nucleophile to the substrate. ${ }^{24}$

The activation parameters for $4\left(\Delta H^{\ddagger}=12-15 \mathrm{kcal} \mathrm{mol}^{-1}\right.$ and $\Delta S^{\ddagger}=-34$ to $\left.-37 \mathrm{cal} \mathrm{mol}^{-1} \mathrm{~K}^{-1}\right)$ and $\mathbf{5}\left(\Delta H^{\mp}=14-16\right.$ kcal $\mathrm{mol}^{-1}$ and $\Delta S^{ \pm}=-30$ to $-33 \mathrm{cal} \mathrm{mol}^{-1} \mathrm{~K}^{-1}$ ) are summarized in Table 3. The activation enthalpies for the pyridinolysis are slightly larger than those for the aminolysis with benzylamines $\left(\Delta H^{\ddagger}=9-13\right.$ and $10-15 \mathrm{kcal} \mathrm{mol}^{-1}$ for $\mathbf{4}$ and 5 , respectively) ${ }^{6 \mathrm{~d}}$ while the activation entropies for pyridinolysis are smaller than those for aminolysis with benzylamines $\left(\Delta S^{\neq}=-20\right.$ to -30 and $\Delta S^{\neq}=-14$ to -28 cal $\mathrm{mol}^{-1} \mathrm{~K}^{-1}$ for $\mathbf{4}$ and $\mathbf{5}$, respectively). ${ }^{6 \mathrm{~d}}$ These suggest that the degree of bond formation for pyridinolysis is larger than that for aminolysis with benzylamines in the bond formation step.

Finally, we can interpret the pyridinolysis of $\alpha$-chloro-

Table 3. Activation parameters ${ }^{a}$ for the reactions of $N-\mathrm{R}-\mathrm{Y}-\alpha-$ chloroacetanilides with X-pyridines in DMSO

\begin{tabular}{|c|c|c|c|c|c|c|}
\hline $\mathrm{R}$ & $X$ & $\mathrm{Y}$ & $\begin{array}{c}\text { Temp. } \\
\left({ }^{\circ} \mathrm{C}\right)\end{array}$ & $\begin{array}{l}k_{\mathrm{N}} \times 10^{4} \\
\left(\mathrm{M}^{-1} \mathrm{~s}^{-1}\right)\end{array}$ & $\begin{array}{c}\Delta H^{+} \\
\left(\mathrm{kcal} \mathrm{mol}^{-1}\right)\end{array}$ & $\begin{array}{c}-\Delta S^{ \pm} \\
\left.\text {al } \mathrm{mol}^{-1} \mathrm{~K}^{-1}\right)\end{array}$ \\
\hline \multirow{12}{*}{$\begin{array}{c}\mathrm{H} \\
\text { (4) }\end{array}$} & \multirow{6}{*}{$p-\mathrm{CH}_{3} \mathrm{O}$} & \multirow[t]{3}{*}{$p-\mathrm{NO}_{2}$} & 75 & 7.79 & \multirow[t]{3}{*}{$12.5 \pm 0.3^{b}$} & \multirow[t]{3}{*}{$37 \pm 1$} \\
\hline & & & 85 & 13.1 & & \\
\hline & & & 95 & 21.3 & & \\
\hline & & $\mathrm{H}$ & 75 & 12.4 & $13.4 \pm 0.2$ & $34 \pm 1$ \\
\hline & & & 85 & 22.0 & & \\
\hline & & & 95 & 35.4 & & \multirow{4}{*}{$32 \pm 1$} \\
\hline & $m-\mathrm{C}_{6} \mathrm{H}_{5}$ & $p-\mathrm{Cl}$ & 75 & 4.10 & \multirow[t]{3}{*}{$14.6 \pm 0.2$} & \\
\hline & & & 85 & 7.42 & & \\
\hline & & & 95 & 13.1 & & \\
\hline & \multirow[t]{3}{*}{$\mathrm{H}$} & \multirow[t]{3}{*}{$\mathrm{H}$} & 75 & 4.99 & \multirow[t]{3}{*}{$14.0 \pm 0.2$} & \multirow[t]{3}{*}{$34 \pm 1$} \\
\hline & & & 85 & 8.99 & & \\
\hline & & & 95 & 15.2 & & \\
\hline \multirow{12}{*}{$\begin{array}{c}\mathrm{CH}_{3} \\
\text { (5) }\end{array}$} & \multirow[t]{3}{*}{$\mathrm{H}$} & \multirow{3}{*}{$p-\mathrm{NO}_{2}$} & 75 & 5.58 & \multirow[t]{3}{*}{$14.4 \pm 0.3$} & \multirow[t]{3}{*}{$33 \pm 1$} \\
\hline & & & 85 & 10.1 & & \\
\hline & & & 95 & 17.1 & & \\
\hline & \multirow[t]{3}{*}{$p-\mathrm{CH}_{3} \mathrm{O}$} & \multirow[t]{3}{*}{$\mathrm{H}$} & 75 & 8.86 & \multirow[t]{3}{*}{$13.8 \pm 0.3$} & \multirow[t]{3}{*}{$33 \pm 1$} \\
\hline & & & 85 & 16.2 & & \\
\hline & & & 95 & 26.7 & & \\
\hline & \multirow{3}{*}{$m-\mathrm{C}_{6} \mathrm{H}_{5}$} & \multirow[t]{3}{*}{$p-\mathrm{Cl}$} & 75 & 3.36 & \multirow[t]{3}{*}{$14.7 \pm 0.2$} & \multirow[t]{3}{*}{$32 \pm 1$} \\
\hline & & & 85 & 6.15 & & \\
\hline & & & 95 & 10.8 & & \\
\hline & \multirow[t]{3}{*}{$\mathrm{H}$} & \multirow[t]{3}{*}{$\mathrm{H}$} & 75 & 2.94 & \multirow[t]{3}{*}{$15.5 \pm 0.2$} & \multirow[t]{3}{*}{$30 \pm 1$} \\
\hline & & & 85 & 5.61 & & \\
\hline & & & 95 & 10.2 & & \\
\hline
\end{tabular}

${ }^{a}$ Calculated by Eyring equation. ${ }^{b}$ Standard deviation 
acetanilides as a stepwise with rate-limiting formation of zwitterionic tetrahedral intermediate, based on Hammett constants $\rho_{\mathrm{X}}$ and $\rho_{\mathrm{Y}}$, Brønsted coefficients $\beta_{\mathrm{X}}$, cross-interaction constants $\rho_{\mathrm{XY}}, \mathrm{RSP}$ and activation parameters. The enolate-like transition state and an alternative reaction path through an epoxide type transition state are ruled out based on the previous works. ${ }^{6 \mathrm{~d}, \mathrm{e}}$

\section{Experimental Section}

Materials. Aldrich GR grade pyridines were used without further purification. All other materials were as reported previously. ${ }^{6 \mathrm{~d}}$

Kinetic Procedure. Rate constants were determined as described previously. ${ }^{6 \mathrm{~d}}$ For the present work, [Substrate] $=1$ $\times 10^{-3}$ and $[\mathrm{Py}]=0.13-0.21 \mathrm{M}$ were used.

Product Analysis. $p$-Nitro- and $N$-methyl $p$-nitro- $\alpha$ chloroacetanilides $(0.0003$ moles $)$ were refluxed with 4 picoline $(0.003$ moles $)$ in $40 \mathrm{~mL}$ acetonitrile at $95{ }^{\circ} \mathrm{C}$. After more than 15 half-lives, solvent was removed under reduced pressure and the product was purified by washing several times with ether. Analytical data of the product gave the following results:

p- $\mathrm{NO}_{2} \mathrm{C}_{6} \mathrm{H}_{4} \mathrm{NHC}(=\mathrm{O}) \mathrm{CH}_{2} \mathrm{~N}^{+} \mathrm{C}_{5} \mathrm{H}_{4}-\boldsymbol{p}-\mathrm{CH}_{3} \mathrm{Cl}^{-}$. White solid; mp $248{ }^{\circ} \mathrm{C}$; $\delta_{\mathrm{H}}\left(200 \mathrm{MHz}, \mathrm{DMSO}-d_{6}\right) 2.66(3 \mathrm{H}, \mathrm{s}$, $\left.\mathrm{CH}_{3}\right), 5.69\left(2 \mathrm{H}, \mathrm{s}, \mathrm{CH}_{2}\right), 11.7(1 \mathrm{H}, \mathrm{s}, \mathrm{NH}), 7.89(2 \mathrm{H}, \mathrm{d}, J=$ $9.2 \mathrm{~Hz}$, benzene), 8.05 ( $2 \mathrm{H}, \mathrm{d}, J=6.6 \mathrm{~Hz}$, pyridine), 8.27 $(2 \mathrm{H}, \mathrm{d}, J=9.6 \mathrm{~Hz}$, benzene), $8.90(2 \mathrm{H}, \mathrm{d}, J=7.0 \mathrm{~Hz}$, pyridine); $\delta_{\mathrm{C}}\left(50 \mathrm{MHz}, \mathrm{DMSO}-d_{6}\right) 22.3,62.2,119.7,125.8$, $128.5,143.4,145.1,146.0,160.6,165.3 ; v_{\max }$ (nujol mull) 3469, 3389, 1716, 1563, 1258. Anal. Calcd for $\mathrm{C}_{14} \mathrm{H}_{14} \mathrm{ClN}_{3} \mathrm{O}_{3}$ : C, 54.6; H, 4.6; N, 13.7. Found: C, 54.5; H, 4.7; N, 13.6.

p- $\mathrm{NO}_{2} \mathrm{C}_{6} \mathrm{H}_{4} \mathbf{N}\left(\mathrm{CH}_{3}\right) \mathbf{C}(=\mathrm{O}) \mathrm{CH}_{2} \mathbf{N}^{+} \mathbf{C}_{5} \mathrm{H}_{4}-\boldsymbol{p}-\mathrm{CH}_{3} \mathrm{Cl}^{-}$. White solid; mp $242{ }^{\circ} \mathrm{C} ; \delta_{\mathrm{H}}\left(200 \mathrm{MHz}, \mathrm{DMSO}-d_{6}\right) 2.62\left(3 \mathrm{H}, \mathrm{s}, \mathrm{CH}_{3}\right)$, $3.36\left(3 \mathrm{H}, \mathrm{s}, \mathrm{N}-\mathrm{CH}_{3}\right), 5.70\left(2 \mathrm{H}, \mathrm{bs}, \mathrm{CH}_{2}\right), 7.82(2 \mathrm{H}, \mathrm{d}, J=7.0$ $\mathrm{Hz}$, benzene), $8.02(2 \mathrm{H}, \mathrm{d}, J=6.2 \mathrm{~Hz}$, pyridine), $8.35(2 \mathrm{H}, \mathrm{d}, J$ $=8.4 \mathrm{~Hz}$, benzene $), 8.87(2 \mathrm{H}, \mathrm{d}, J=6.4 \mathrm{~Hz}$, pyridine $) ; \delta_{\mathrm{C}}(50$ MHz, DMSO- $\left.d_{6}\right)$ 21.6, 37.0, 60.9, 124.7, 127.8, 129.2, 145.2, 145.4, 147.7, 159.8, 165.1; $v_{\max }$ (nujol mull) 3560, 3397, 1681, 1518, 1295. Anal. Calcd. for $\mathrm{C}_{15} \mathrm{H}_{16} \mathrm{ClN}_{3} \mathrm{O}_{3}: \mathrm{C}, 56.0 \mathrm{H}$, 5.0; N, 13.1. Found: C, 55.8; H, 5.2; N, 13.2.

Acknowledgement. This work was supported by Korea Research Foundation Grant (KRF-2002-070-C00061).

\section{References}

1. (a) Dewar, M. J. S. The Electronic Theory of Organic Chemistry; Oxford University Press: Oxford, 1949; p 73. (b) McLennan, D. J.; Pross, A. J. Chem. Soc. Perkin Trans. 2 1984, 981. (c) Pross, A.; Aviram, K.; Klix, R. C.; Kost, D.; Back, R. D. New J. Chem. 1984, 8, 711. (d) Shaik, S. S. J. Am. Chem. Soc. 1983, 105, 4359. (e) Pross, A.; De Frees, D. J.; Levi, B. A.; Pollack, S. K.; Radom, L.; Hehre, W. J. J. Org. Chem. 1981, 46, 1693. (f) Kost, D.; Aviram, K. Tetrahedron Lett. 1982, 23, 4157. (g) Wolfe, S.; Mitchell, D. J.; Schelegel, H. B. Can. J. Chem. 1982, 60, 1291.

2. (a) Conant, J. B.; Kirner, W. R. J. Am. Chem. Soc. 1924, 46, 232. (b) Ross, S. D.; Finkelstein, M.; Petersen, R. C. J. Am. Chem. Soc. 1968, 90, 6411. (c) Halvorsen, A.; Songstad, J. J. Chem. Soc.,
Chem. Commun. 1978, 327. (d) Bartlett, P. D.; Trachtenberg, E. N. J. Am. Chem. Soc. 1958, 80, 15808. (e) Thorpe, J. W.; Warkentin, J. Can. J. Chem. 1973, 51, 927. (f) Bordwell, F. G.; Brannen, W. T. J. Am. Chem. Soc. 1964, 86, 4645. (g) Lee, I.; Sung, D. D. Curr. Org. Chem. 2004, 8, 557.

3. Streitwieser, Jr., A. Solvolytic Displacement Reactions; McGrawHill: NewYork, 1962.

4. (a) Baker, J. W. Trans Faraday Soc. 1951, 37, 643. (b) Bunton, C. A. Nucleophilic Substitution at a Saturated Carbon Atom; Elsevier: New York, 1963; p 5. (c) Winstein, S.; Grunwald, E.; Jones, H. W. J. Am. Chem. Soc. 1951, 73, 2700.

5. (a) Yousaf, T. I.; Lewis, E. S. J. Am. Chem. Soc. 1987, 109, 6137. (b) Forster, W.; Laird, R. M. J. Chem. Soc., Perkin Trans. 2 1982, 135.

6. (a) Lee, I.; Shim, C. S.; Chung, S. Y.; Lee, H. W. J. Chem. Soc., Perkin Trans. 2 1988, 975. (b) Lee, I.; Shim, C. S.; Lee, H. W. J. Phys. Org. Chem. 1989, 2, 484. (c) Koh, H. J.; Han, K. L.; Lee, H. W.; Lee, I. J. Org. Chem. 2000, 65, 4706. (d) Lee, K. S.; Adhikary, K. K.; Lee, H. W.; Lee, B.-S.; Lee, I. Org. Biomol. Chem. 2003, 1, 1989. (e) Lee, I.; Lee, H. W.; Yu, Y.-K. Bull. Korean Chem. Soc. 2003, 24, 993

7. (a) Lee, I. Chem. Soc. Rev. 1990, 19, 317. (b) Lee, I. Adv. Phys. Org. Chem. 1992, 27, 57. (c) Lee, I.; Lee, H. W. Collect. Czech. Chem. Commun. 1999, 64, 1529.

8. Hansch, C.; Leo, A.; Taft, R. W. Chem. Rev. 1991, 91, 165.

9. Dean, J. A. Handbook of Organic Chemistry; MaGraw-Hill: New York, ch. 8, 1987.

10. (a) Lee, I.; Hong, S. W.; Koh, H. J.; Lee, Y.; Lee, B.-S.; Lee, H. W. J. Org. Chem. 2001, 66, 8549. (b) Kim, T.-H.; Huh, C.; Lee, B.-S.; Lee, I. J. Chem. Soc., Perkin Trans. 2 1995, 2257. (c) Koh, H. J.; Kim, T. H.; Lee, B.-S.; Lee, I. J. Chem. Res. $(S)$ 1996, 482.

11. Spillane, W. J.; Hogan, G.; McGrath, P.; King, J.; Brack, C. J. Chem. Soc., Perkin Trans. 2 1996, 2099.

12. (a) Fukui, K. Theory of Orientation and Stereoselection; Springerverlag: Berlin, 1975. (b) Fleming, I. Frontier Orbitals and Organic Chemical Reactions; Wiley: London, 1976. (c) Li, H. G.; Kim, C. K.; Lee, B.-S.; Kim, C. K.; Rhee, S. K.; Lee, I. J. Am. Chem. Soc. 2002, 123, 2326.

13. (a) Castro, E. A.; Sales, M. J.; Santos, J. G. J. Org. Chem. 1994, 59, 30. (b) Castro, E. A.; Leandro, L.; Millan, P.; Santos, J. G. J. Org. Chem. 1999, 64, 1953. (c) Castro, E. A.; Munoz, P.; Santos, J. G. J. Org. Chem. 1999, 64, 8298. (d) Oh, H. K.; Kim, S. K.; Cho, I. H.; Lee, H. W.; Lee, I. J. Chem. Soc., Perkin Trans. 2 2000, 2306.

14. (a) Koh, H. J.; Lee, H. C.; Lee, H. W.; Lee, I. Bull. Korean Chem. Soc. 1995, 16, 839. (b) Lee, B. C.; Yoon, J. H.; Lee, C. G.; Lee, I. J. Phys. Org. Chem. 1994, 7, 273.

15. (a) Lee, I.; Shim, C. S.; Lee, H. W. J. Chem. Res. (S) 1992, 90. (b) Lee, I.; Koh, H. J. New J. Chem. 1996, 20, 131. (c) Oh, H. K.; Shin, C. H.; Lee, I. J. Chem. Soc., Perkin Trans. 2 1995, 1169.

16. (a) Lee, I. Bull. Korean Chem. Soc. 1994, 15, 985. (b) Yew, K. H.; Koh, H. J.; Lee, H. W.; Lee, I. J. Chem. Soc., Perkin Trans. 2 $1995,2263$.

17. (a) Gresser, M. J.; Jencks, W. P. J. Am. Chem. Soc. 1977, 99, 6970. (b) Castro, E. A.; Steinfort, G. B. J. Chem. Soc., Perkin Trans. 2 1983, 453. (c) Song, B. D.; Jencks, W. P. J. Am. Chem. Soc. 1989, 111,8479 .

18. Oh, H. K.; Shin, C. H.; Lee, I. Bull. Korean. Chem. Soc. 1995, 16, 657.

19. Oh, H. K.; Lee, J. M.; Lee, H. W.; Lee, I. Int. J. Chem. Kinet. 2004, 36, 434 .

20. Oh, H. K.; Ku, M. H.; Lee, H. W.; Lee, I. J. Org. Chem. 2002, 67, 3874.

21. Oh, H. K.; Ku, M. H.; Lee, H. W.; Lee, I. J. Org. Chem. 2002, 67, 8995.

22. Satterthwait, A. C.; Jencks, W. P. J. Am. Chem. Soc. 1974, 96, 7018.

23. Castro, E. A.; Aliaga, M.; Compodonico, P.; Santos, J. G. J. Org. Chem. 2002, 67, 8911.

24. (a) Pross, A. Adv. Phys. Org. Chem. 1977, 14, 69. (b) Buncel, E.; Wilson, H. J. Chem. Edu. 1987, 64, 475. 